\title{
Identification of a new strain of Actinomadura isolated from Saharan soil and partial characterization of its antifungal compounds
}

\author{
Boubekeur Badji $^{1 \star}$, Abdallah Mostefaoui ${ }^{1}$, Nasserdine Sabaou${ }^{1}$ and Florence Mathieu ${ }^{2}$ and \\ Ahmed Lebrihi ${ }^{2}$. \\ ${ }^{1}$ Laboratoire de Recherche sur les Produits Bioactifs et la Valorisation de la Biomasse, Ecole Normale Supérieure de \\ Kouba, B.P. 92, 16050 Vieux- Kouba, Alger, Algérie. \\ ${ }^{2}$ Laboratoire de génie chimique UMR 5503 (CNRS/INPT/UPS), Ecole Nationale Supérieure Agronomique de \\ Toulouse, INPT, 1, avenue de l'Agrobiopôle, BP 107, F31326 Castanet-Tolosan cedex, France.
}

Accepted 1 September, 2011

\begin{abstract}
One promising strain Actinomadura sp. AC170, isolated from Algerian Saharan soil, with strong antifungal activity against pathogenic and toxinogenic fungi, was selected for further studies. The $16 \mathrm{~S}$ rRNA results showed a distinct phylogenetic lineage from the other species within the Actinomadura genus. The production of antibiotic substances was investigated using GYEA solid medium. The butanolic extract contained four bioactive spots detected on thin layer chromatography plates. Among these antibiotics, a complex called $170 \mathrm{~A}$, which showed the more interesting antifungal activity, was selected and purified by reverse-phase HPLC. This complex is composed of four compounds. Ultraviolet-visible, infrared, mass and $\mathrm{H}$ nuclear magnetic resonance spectroscopy studies showed that these molecules contain an aromatic ring substituted by aliphatic chains. These compounds differ from the known antibiotics produced by Actinomadura species.
\end{abstract}

Key words: Actinomadura, taxonomy, antifungal compounds, Saharan soil.

\section{INTRODUCTION}

Actinomycetes are Gram positive bacteria having a high $\mathrm{G}+\mathrm{C}(>55 \%)$ and are well known as a rich source of bioactive molecules. They are responsible for the production of about half of the discovered bioactive secondary metabolites (Berdy, 2005).

One of the strategies to increase the possibility of discovering novel chemical entities is to screen actionmycetes considered rare in the extreme environments (Gathogo et al., 2004). Among these rare actinomycetes, the genus Actinomadura is reported to be the most predominant (Miyadoh, 1993). This fact shows that this genus received increasing attention and is considered as one of the most important targets in screening programs for bioactive metabolites (Dairi et al., 1999; Zakharova et al., 2003). The genus Actinomadura belongs to the family of Thermomonosporaceae (Zhang et al., 2001). Currently,

\footnotetext{
*Corresponding author. E-mail: badji_boubekeur@yahoo.fr
} Tel/Fax: 00.213 (0) 21287981. it contains 37 species including 2 subspecies (Euzeby, 2010).

Previous studies have reported the abundance and diversity of actinomycetes in Algerian Saharan soils (Sabaou et al., 1998). During the course of our investigation on those soils, a strain designated $\mathrm{AC} 170$, was shown to have chemical and morphological properties typical of members of the genus Actinomadura. It is selected for its antifungal activity against various pathogenic and toxinogenic fungi (Badji et al., 2005). In this paper, we describe the identification of the isolate and the preliminary characterization of its antifungal products.

\section{MATERIALS AND METHODS}

\section{Taxonomy of the isolate}

Morphological and chemotaxonomic studies of the isolate have been reported by Badji et al. (2005). 


\section{Physiological characteristics}

For the physiological studies, 76 tests commonly used in numerical taxonomy of actinomycetes were applied. Production of melanoid pigments was tested on peptone yeast extract iron agar (ISP6) and tyrosine agar (ISP7) (Shirling and Gottlieb, 1966). Carbohydrates and organic acids assimilation as carbon source and utilization of testosterone were determined as described by Gordon et al. (1974) and Goodfellow et al. (1979). Decomposition of adenine, guanine, hypoxanthine, tyrosine and xanthine were determined by the methods of Gordon et al. (1974) and arbutin and aesculin decomposition, gelatin liquefaction, starch, Tween 80 hydrolysis and nitrate reductase production were determined as described by Marchal and Bourdon (1973). The strain was also examined for its ability to grow on glucose-yeast extract agar (GYEA) medium (Athalye et al., 1985) supplemented with 15 different antibiotics and inhibitory compounds including lysozyme (Gordon and Barnett, 1977), phenol, potassium tellurite, sodium azide, sodium chloride and violet crystal. Growth at different temperatures and $\mathrm{pH}$ were also tested in the same medium.

\section{DNA preparation, PCR amplification, sequence and phylogenetic analysis}

The isolate AC170 was grown on ISP2 solid medium (malt extract, $10 \mathrm{~g}$; yeast extract, $4 \mathrm{~g}$; glucose, $4 \mathrm{~g}$; agar, $18 \mathrm{~g} ; 1000 \mathrm{ml}$ distilled water; $\mathrm{pH} 7.2$ ) for 9 days at $28^{\circ} \mathrm{C}$. The mycelium was scraped and washed twice with double-distilled water. About $200 \mathrm{mg}$ of mycelia was used for DNA extraction as follows: the sample was dispersed in $800 \mu \mathrm{l}$ of the aqueous lysis solution $(100 \mathrm{mmol} / \mathrm{l}$ Tris- $\mathrm{HCl}, \mathrm{pH} 7$; $20 \mathrm{mmol} / \mathrm{l}$ EDTA; $250 \mathrm{mmol} / \mathrm{l} \mathrm{NaCl} ; 2 \% \mathrm{~m} / \mathrm{v}$ SDS; $1 \mathrm{mg} / \mathrm{ml}$

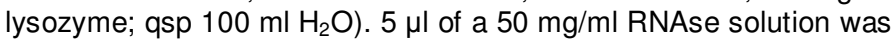
added and the suspension incubated at $37^{\circ} \mathrm{C}$ for $60 \mathrm{~min}$. Ten microliters of a proteinase $\mathrm{K}$ solution $(20 \mathrm{mg} / \mathrm{ml})$ was added and the lysis solution was re-incubated at $65^{\circ} \mathrm{C}$ for $30 \mathrm{~min}$. The lysate was extracted with an equal volume of phenol and centrifuged $(7000 \times$ $g, 10 \mathrm{~min}$ ). The aqueous layer was re-extracted with phenol (50 to $50 \% \mathrm{v} / \mathrm{v}$ ), then by chloroform ( 50 to $50 \% \mathrm{v} / \mathrm{v}$ ). DNA was recovered from the aqueous phase by the addition of $\mathrm{NaCl}(150 \mathrm{mmol} / \mathrm{l}$ final concentration) and 2 volumes of cool $95 \% \mathrm{v} / \mathrm{v}$ ethanol prior to centrifugation. The precipitated DNA was cleaned with $50 \mu \mathrm{l}$ of $70 \%$ $v / v$ ethanol, centrifuged $(7000 \times g, 10 \mathrm{~min})$, resuspended in $50 \mu \mathrm{l}$ of TE buffer $(10 \mathrm{mmol} / \mathrm{l}$ Tris- $\mathrm{HCl}, \mathrm{pH} 7.4 ; 1 \mathrm{mmol} / / \mathrm{EDTA}, \mathrm{pH} 8)$ and stored at $-20^{\circ} \mathrm{C}$. The purity of DNA solutions was checked spectrophotometrically at 260 and $280 \mathrm{~nm}$ and the quantities of DNA were measured at $260 \mathrm{~nm}$.

The 16S rDNA was amplified by using the PCR method with Taq DNA polymerase and primers 27f (5'-AGAGTTTGATCCT GGCTCAG-3') and 1492r (5'- GGTTACCTTGTTACGACTT-3'). The conditions for thermal cycling were as follows: denaturation of the target DNA at $98^{\circ} \mathrm{C}$ for 3 min followed by 30 cycles at $94^{\circ} \mathrm{C}$ for 1 min, primer annealing at $53^{\circ} \mathrm{C}$ for $1 \mathrm{~min}$ and primer extension at $72^{\circ} \mathrm{C}$ for $5 \mathrm{~min}$. At the end of the cycling, the reaction mixture was held at $72^{\circ} \mathrm{C}$ for $5 \mathrm{~min}$ and then cooled to $4^{\circ} \mathrm{C}$. PCR amplification was detected by agarose gel electrophoresis and was visualized by ultraviolet (UV) fluorescence after ethidium bromide staining.

The PCR product obtained was submitted to GenomExpress (Meylan, France) for sequence determination. The same primers as above and an automated sequencer were used for this purpose. The sequence was compared for similarity with the reference species of bacteria contained in genomic database banks, using the NCBI BLAST available at http://www.ncbi-nlm-nih.gov/. Phylogenetic analyses were conducted using software included in MEGA Version 3.0 (Kumar et al., 2004) package. The 16S rDNAsequence of the strain AC170 was aligned using the Clustal W program (Thompson et al., 1994) against corresponding nucleotide sequences of representatives of the genus Actinomadura retrieved from GenBank. Evolutionary distance matrices were generated as described by Jukes and Cantor (1969) and a phylogenetic tree was inferred by the neighbour joining method (Saitou and Nei, 1987). Tree topologies were evaluated by bootstrap analysis (Felsenstein, 1985) based on 1000 resamplings of the neighbour joining dataset.

\section{Antimicrobial activity}

The spectrum of activity of the strain AC170 was determined against several filamentous fungi, yeasts, Gram-positive and Gramnegative bacteria. The microorganisms are listed in Table 2. The experiments were done by streaking a straight line of the AC170 inoculum across the surface of glucose yeast extract malt extract agar (ISP2) medium on plate. After incubation for 7 days at $30^{\circ} \mathrm{C}$, the bioassay organisms were streaked at right angles to the strain AC170 (straight line). The plates were incubated at $30^{\circ} \mathrm{C}$ and observed for antibiosis on the first and the second day. The extent of growth inhibition of the bioassay organisms was recorded by measuring the length of the inhibition range away from the strain AC170.

\section{Isolation and purification of antimicrobial products}

Strain AC170 has a particularity to grow only on solid media. The antimicrobial activity is better on GYEA (Glucose-extract of yeast agar) (Badji et al., 2005). The production of antibiotics was thus, carried out on this medium incubated during 21 days at $28^{\circ} \mathrm{C}$. The 1 $\mathrm{L}$ of culture broth was extracted twice with $n$-butanol and was concentrated to dryness in vacuo. The crude extract was dissolved in methanol and applied to a thin-layer chromatography silica gel plate (Merck 60 F 254; Merck, Darmstadt, Germany), which was developed with $n$-butanol - ethyl acetate-water $(3 / 1 / 1, v / v / v)$. The spots were detected by bioautography (Betina, 1973) on silica gel plates seeded with Mucor ramannianus or Bacillus subtilis. The active spots were also visualized under UV irradiation at 254 and $365 \mathrm{~nm}$. The fraction that showed more antifungal activity was purified by semi-preparative high-pressure liquid chromatography on reversed-phase material, under the following conditions: Uptisphere UP 15 WOD C18 column (300 × $7.8 \mathrm{~mm}$ Interchim); mobile phase, gradient elution system of methanol-water; flow rate, $2 \mathrm{ml} / \mathrm{min}$; UV detection at $220 \mathrm{~nm}$ at room temperature.

\section{Partial characterization of products}

The spectroscopic studies were made with the pure antifungal compounds. UV-visible absorption spectra were recorded on a Lambda 20 spectrophotometer (Perkin-Elmer, Wellesley, Massachusetts, USA) and an infrared spectrum was obtained on a FT-IR $1760 \times$ spectrometer (Perkin-EImer).

Mass spectrum was recorded on LCQ ion-trap mass spectrometer (Finnigan MAT, San Jose, California, USA) equipped with a nanospray ion ESI source (negative ion mode). Proton magnetic resonance (1 $\mathrm{H} \mathrm{NMR}$ ) was recorded at $300 \mathrm{MHz}$ using a Bruker AC-300 spectrometer (Bruker Instruments, Billerica, Massachusetts, USA).

\section{RESULTS AND DISCUSSION}

\section{Taxonomy of the isolate}

Physiologically, AC170 uses less carbonaceous sources 
Table 1. Physiological characteristics of Actinomadura sp. AC170.

\begin{tabular}{|c|c|c|c|}
\hline Test & Result & Test & Result \\
\hline \multicolumn{2}{|l|}{ Hydrolysis of: } & \multicolumn{2}{|l|}{ Decarboxylation of sodium salts: } \\
\hline Adenine & - & Acetate & + \\
\hline Aesculin & - & Benzoate & - \\
\hline Arbutin & - & Butyrate & - \\
\hline Casein & + & Citrate & - \\
\hline Gelatin & + & Oxalate & - \\
\hline Guanine & - & Propionate & - \\
\hline Hypoxanthine & - & Pyruvate & - \\
\hline Starch & + & Succinate & - \\
\hline Testosterone & - & Tartrate & - \\
\hline Tween 80 & + & & \\
\hline Tyrosine & - & Growth in presence of $(\mathrm{g} / \mathrm{l})$ : & \\
\hline \multirow[t]{2}{*}{ Xanthine } & - & Crystal violet $(0.01)$ & + \\
\hline & & Crystal violet $(0.1)$ & - \\
\hline \multicolumn{2}{|c|}{ Utilization of glucides and derivatives: } & $\mathrm{NaCl}(30)$ & + \\
\hline \multicolumn{2}{|l|}{$\begin{array}{l}\text { Adonitol } \\
\text { Arabinose }\end{array}$} & $\mathrm{NaCl}(50)$ & - \\
\hline Arabinose & & & \\
\hline \multicolumn{2}{|l|}{ Cellobiose } & Lysozyme (0.05) & + \\
\hline Dextrin & - & Phenol (0.5) & - \\
\hline Dulcitol & - & Potassium tellurite $(0.1)$ & + \\
\hline Erythritol & + & Sodium azide (0.05) & + \\
\hline Fructose & - & Sodium azide $(0.1)$ & - \\
\hline Galactose & - & & \\
\hline Glucose & - & \multicolumn{2}{|l|}{ Growth at: } \\
\hline$\propto-$ Methyl-D-glucoside & - & $45^{\circ} \mathrm{C}$ & - \\
\hline Glycerol & + & $\mathrm{pH} 5$ & - \\
\hline Inositol & - & $\mathrm{pH} 9$ & + \\
\hline Lactose & + & & \\
\hline Maltose & + & \multicolumn{2}{|l|}{ Growth in the presence of antibiotics (mg/l) } \\
\hline Mannitol & - & \multicolumn{2}{|l|}{ Ampicillin (75) } \\
\hline Mannose & - & Chloramphenicol (25) & + \\
\hline Melibiose & - & Cycloserin (25) & + \\
\hline Melezitose & - & Erythromycin (10) & + \\
\hline Raffinose & - & Gentamicin (5) & + \\
\hline Rhamnose & - & Kanamycin (25) & - \\
\hline Ribose & - & Novobiocin (10) & + \\
\hline Sorbitol & - & Oleandomycin (75) & + \\
\hline Sucrose & - & Oxytetracycline (25) & + \\
\hline Trehalose & - & Penicillin (10) & - \\
\hline D-Xylose & - & Rifamycin (5) & + \\
\hline Nitrate reduction & + & Streptomycin (10) & + \\
\hline \multirow[t]{4}{*}{ Melanoid pigments } & - & Sulfanylamide (75) & + \\
\hline & + & Thiostrepton (75) & + \\
\hline & - & Vancomycin (5) & + \\
\hline & & Ampicillin (75) & - \\
\hline
\end{tabular}

+, Positive test; -, negative test.

but resists to a great numbers of antibiotics tested (Table 1). The isolate was able to hydrolyze a few numbers of compounds such as casein, gelatin, starch, Tween 80 , dextrin, glucose, glycerol, inositol, trehalose and sodium acetate. It was resistant to crystal violet $(0.01 \mathrm{~g} / \mathrm{l})$, Lysozyme $(0.05 \mathrm{~g} / \mathrm{l})$, potassium tellurite $(0.1 \mathrm{~g} / \mathrm{l})$, sodium 
Table 2. Antimicrobial activity of the strain AC170.

\begin{tabular}{lc}
\hline Bioassay organisms & Inhibition zone (mm) \\
\hline Alternaria sp. & 18 \\
Ascochyta lentis & 43 \\
Ascochyta pisi & 42 \\
Aspergillus sp. & 20 \\
Botrytis fabae & 42 \\
Botrytis cinerea & 12 \\
Cladosporium $\mathrm{sp}$. & 31 \\
Fusarium culmorum & 31 \\
F. equiseti & 26 \\
F. oxysporum f.sp. albedinis & 9 \\
Mucor ramannianus & 21 \\
Phoma sp. & 45 \\
Pythium irregulare & 14 \\
Rhodotorula mucilginosa & 5 \\
Saccharomyces cerevisiae & 18 \\
Bacillus subtilis & 34 \\
Micrococcus luteus & 27 \\
\hline
\end{tabular}

*Each value represents the average of three measurements.

azide $(0.05 \mathrm{~g} / \mathrm{l})$, sodium chloride $(30 \mathrm{~g} / \mathrm{l})$ and to several antibiotics such as ampicillin $(75 \mathrm{mg} / \mathrm{l})$, chloramphenicol $(25 \mathrm{mg} / \mathrm{l})$, cycloserine $(25 \mathrm{mg} / \mathrm{l})$, erythromycin $(10 \mathrm{mg} / \mathrm{l})$, kanamycin $(25 \mathrm{mg} / \mathrm{l})$, novobiocin $(10 \mathrm{mg} / \mathrm{l})$, oleandomycin (75 mg/l), penicillin (10 mg/l), rifamycin $(5 \mathrm{mg} / \mathrm{l})$, streptomycin $(10 \mathrm{mg} / \mathrm{l})$, sulfanilamide $(75 \mathrm{mg} / \mathrm{l})$ and thiostrepton $(75 \mathrm{mg} / \mathrm{l})$.

Comparing the physiologic properties with the representative species of the Actinomadura genus, our isolated strain could not be assigned to any of the valid representatives listed in Bergey's Manual of Determinative Bacteriology, then it can be identified based on the molecular taxonomic studies. However, it is known that the species of the genus Actinomadura differ from to each other by their metabolic capacity (Toropova et al., 1985) and they are also known for their resistance to antibiotics (Terekhova et al., 1981).

Phylogenetic analysis using the 16S rDNA sequence confirmed that isolate $\mathrm{AC} 170$ belonged to the genus Actinomadura (Figure 1). The comparison between its sequence and those of the species of Actinomadura showed percentages of similarity lower than $97 \%$. These percentages are very low and strongly suggest that strain AC170 is a new species. According to Stackebrandt and Gobel (1994) and Yassin et al. (2010), the species is sour to be new if the percentage of homology of the sequences $16 \mathrm{~s}$ is lower than $97 \%$.

\section{Antimicrobial activity}

The ability of isolate AC170 to inhibit growth of some fungi and bacteria showed very strong (> $40 \mathrm{~mm}$ inhibition zone), strong ( 30 to $40 \mathrm{~mm}$ ), moderate (20 to $30 \mathrm{~mm}$ ), weak (10 to $20 \mathrm{~mm}$ ) and very weak $(<10 \mathrm{~mm})$ antibiosis against some of the test organisms (Table 2). However, this isolate did not show any antibiosis activity against the gram-negative bacteria such as Alcaligenes faecalis, Escherichia coli, Pseudomonas aeruginosa and Pseudomonas fluorescens. These results were observed within 7 days after streaking of the test organisms.

\section{Purification and partial characterization of the antifungal compounds}

On silica gel thin-layer chromatogram, the Butanolic extract was separated into four bioautographic spots with a different retention factor, which were all shown to be active against $B$. subtilis (Table 3 ). The spot designated as $170 \mathrm{~A}$ (retention factor $=0.50$ ), was found to be significantly active against Mucor ramannianus and Saccharomyces cerevisiae.

The complex 170A which showed interesting antifungal activity was selected and purified by reverse-phase highpressure liquid chromatography. The active fractions were eluted with $80 \%$ methanol in water. $170 \mathrm{~A}$ was composed by four components that were designated $170 \mathrm{~A} 1,170 \mathrm{~A} 2,170 \mathrm{~A} 3$ and $170 \mathrm{~A} 4$. These components were recovered separately and reinjected several times until complete purification was achieved.

Spectroscopic studies were carried out for the four compounds. The UV-visible spectra in methanol (Figure 2) for the four components showed no characteristic polyenic chromophore and exhibited the same maxima of absorption with 210 to 212,252 to 254 and $358 \mathrm{~nm}$. 


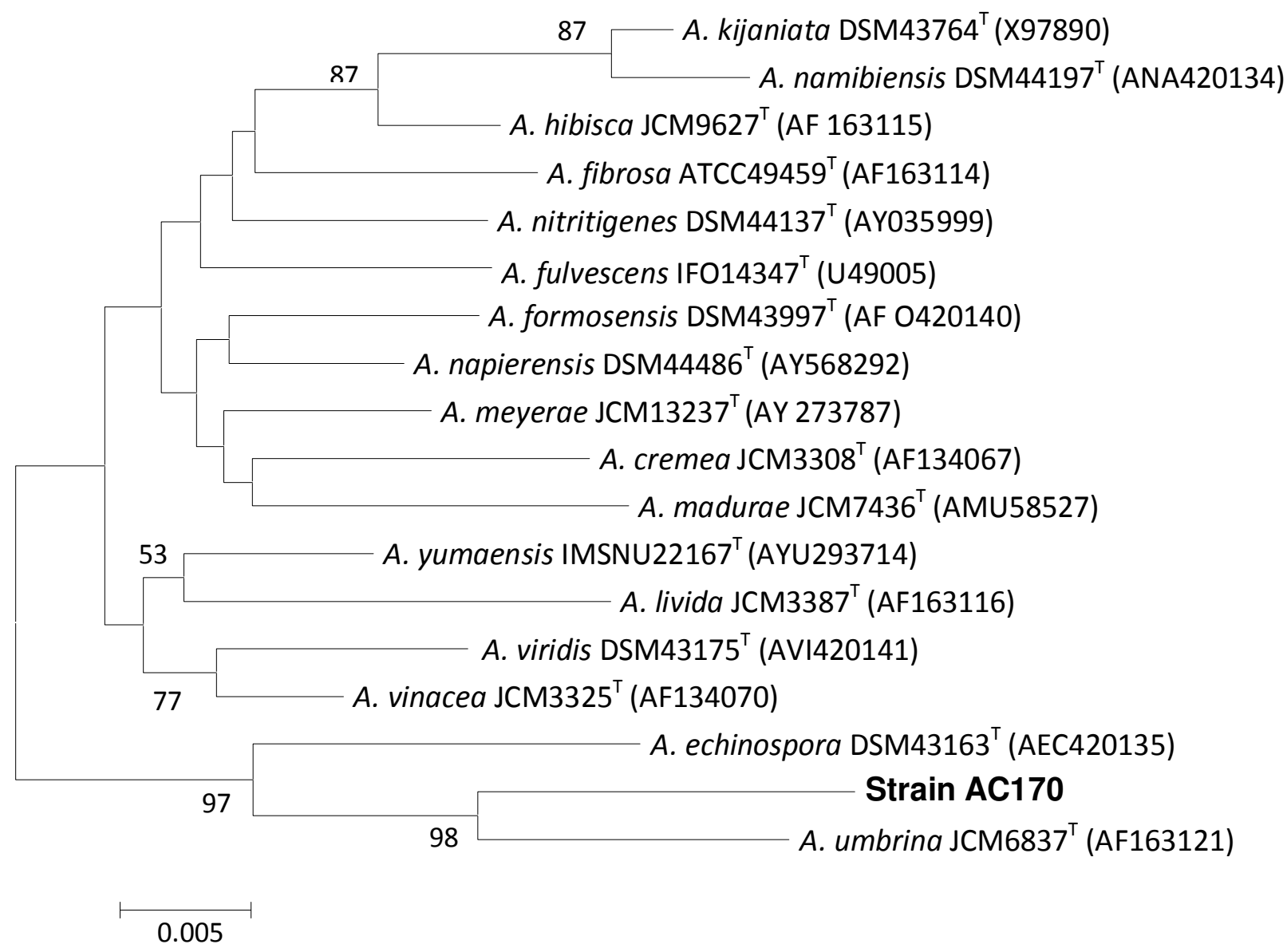

Figure 1. Phylogenetic classification of the Actinomadura AC170 strain based on 16 s rDNA sequence. Numbers at nodes indicate percentages of bootstrap support based on a neighbour joining analysis of 1000 re-sampled datasets; only values above $50 \%$ are given. Bar: 0.005 substitutions per nucleotide position.

Table 3. Crude compounds produced by the strain AC170 on GYEA medium.

\begin{tabular}{cllccc}
\hline \multirow{2}{*}{ Antibiotic } & \multirow{2}{*}{$\mathbf{R f}^{\mathbf{a}}$} & \multirow{2}{*}{ colour under UV $(\mathbf{2 5 4} \mathbf{n m})$} & \multicolumn{3}{c}{ Activity $_{\mathbf{~ ( m m})^{\mathbf{b}}}$} \\
\cline { 4 - 6 } & & & M.r. & S.c. & B.s. \\
\hline $170^{\mathrm{B}}$ & 0.60 & Yellow Brownish brown & 25 & 21 & 33 \\
$170^{\mathrm{A}}$ & 0.50 & Yellowish & 35 & 30 & 48 \\
$170^{\mathrm{C}}$ & 0.38 & Pale yellow & 12 & - & 31 \\
$170^{\mathrm{D}}$ & 0.30 & Not visible & - & - & 19 \\
\hline
\end{tabular}

M.r. $=$ M. ramannianus (NRRL 1829); S.c. = S. cerevisiae (ATCC 4226); B.s. = B. subtilis (ATCC 6633); the Rf of

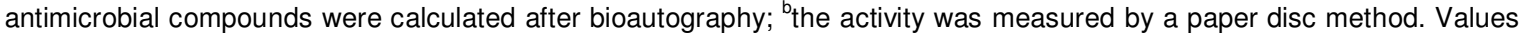
include the diameter of discs $(6 \mathrm{~mm}) ;-$, no activity.

The molecules 170A1 A4 have exactly the same spectrum IR (Figure 3). They show the following characteristics: $3411 \mathrm{~cm}^{-1}$ corresponds to groupings $\mathrm{NH}$ and/or $\mathrm{OH}$. The bands from 2923 to 2853 and 1438 to $1420 \mathrm{~cm}^{-1}$ indicate the presence of $\mathrm{CH}, \mathrm{CH}_{2}$ and $\mathrm{CH}_{3}$ aliphatic. The bands of 1621 to $1484 \mathrm{~cm}^{-1}$ indicate the presence of an aromatic ring. The band at $1348 \mathrm{~cm}^{-1}$ indicates the presence of $\mathrm{OH}$ function. The bands at 1199 and 1172 indicate the presence of a connection CO of the $\mathrm{C}-\mathrm{OH}$.

The mass spectrum of $170 \mathrm{~A} 2$ is illustrated in Figure 4. It was carried out with the method of ionization chemical by desorption in positive mode and using ammonia. The "pseudo-molecular" ions products are as follows: $(\mathrm{M}+\mathrm{H})^{+}$ 


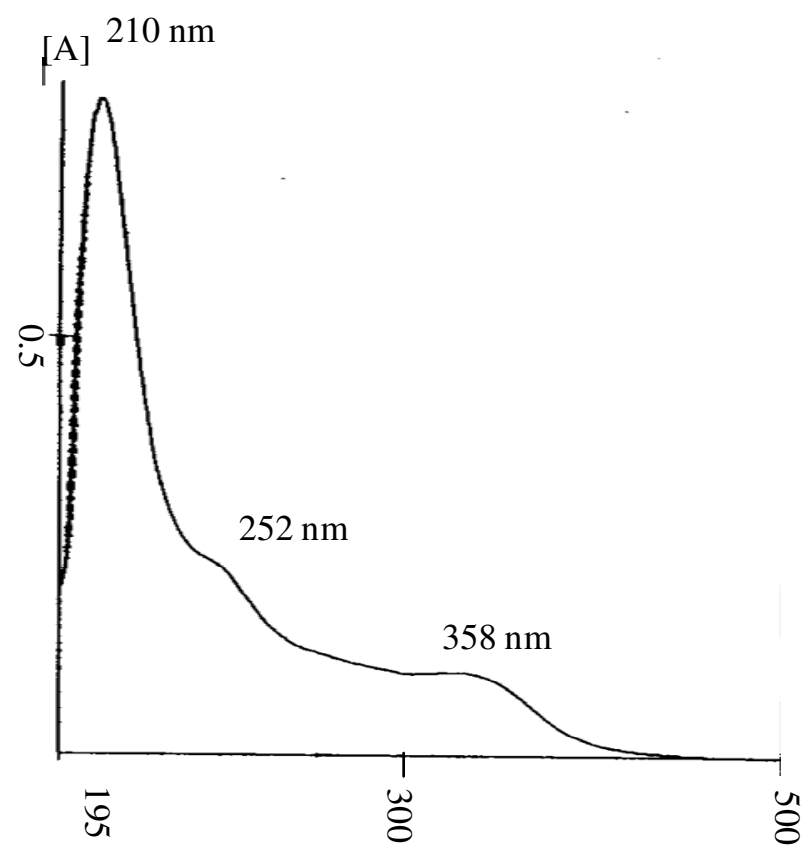

Figure 2. UV-visible spectrum of the 170A2 molecule (in methanol).

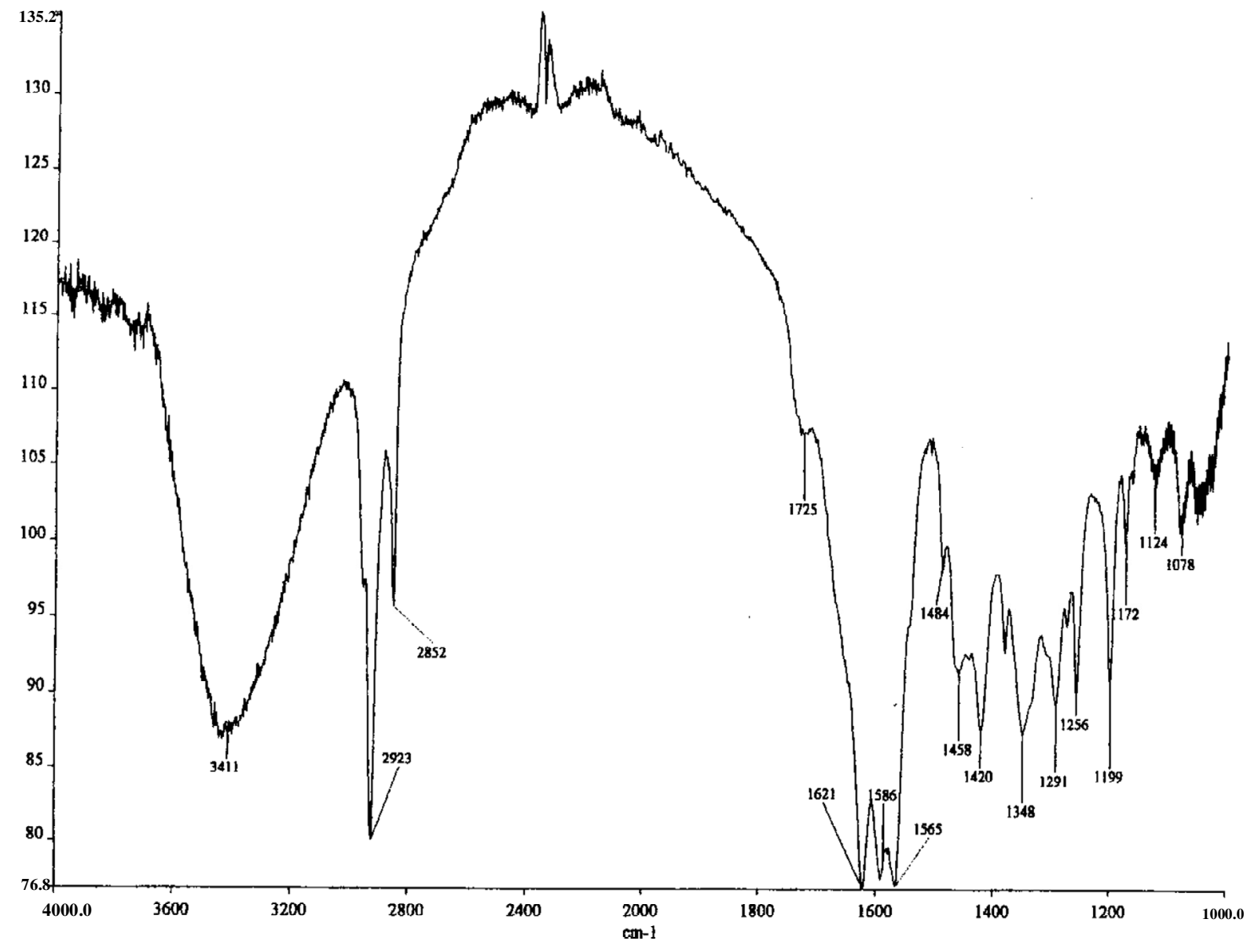

Figure 3. IR spectrum of the 170A2 molecule. 


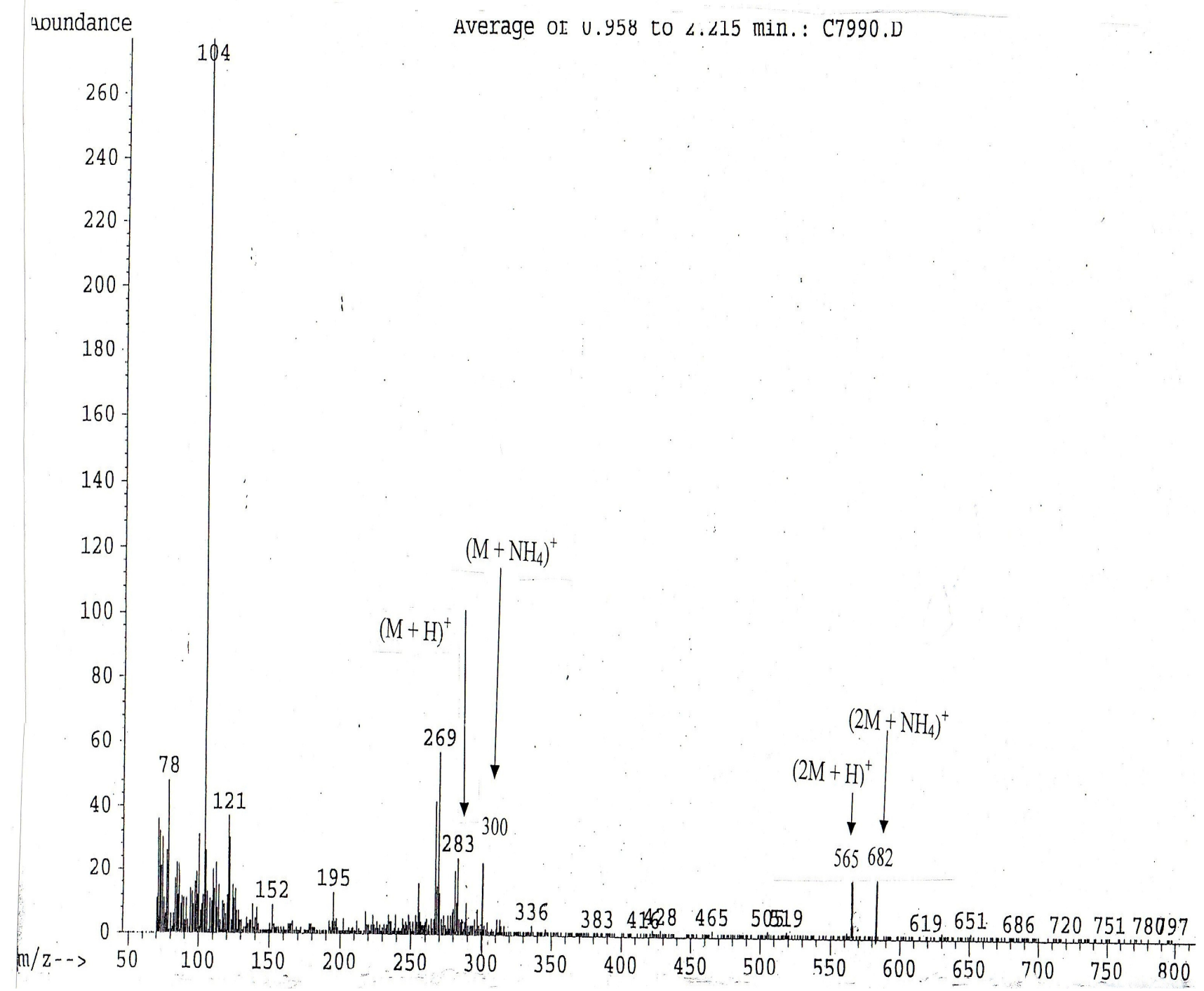

Figure 4. Mass spectrum of the 170A2 molecule (electrospray ion source).

of mass $=283,(\mathrm{M}+\mathrm{NH} 4)^{+}=300,(2 \mathrm{M}+\mathrm{H})^{+}=565$ and $(2 \mathrm{M}+\mathrm{NH} 4)^{+}=582$. The molecular mass of the compound is thus, 282.

$\mathrm{H}$ NMR showed some common main signals in the 0.7 to $3.5 \mathrm{ppm}$ regions indicating the presence of alkyl groupings. The signals at 6.9 and $7.2 \mathrm{ppm}$ indicate the presence of $p$-disubstituted benzenic ring (Figure 5).

Our results suggest that the antibiotics 170A1 A4 belong to the same chemical family containing a benzenic ring disubstituted by aliphatic chains. They look like those produced by a new species Actinomadura AC104, isolated from Saharan soil (Badji et al., 2006). This phenomenon has been reported by Terekhova et al. (1991), which observed that screening of antibioticproducing cultures among Actinomadura showed that definite species mainly produced antibiotics of the same groups.

Actinomadura genus is reported to contain 37 species
(Euzeby, 2010), which produce antibiotics belonging to the polyether and anthracyclin families (Berdy et al., 1987), naphtoquinone family (Kakinuma et al., 1993) and macrolactam family (Hedge et al., 1992). The antibiotics produced by the strain AC170 differ from known bioactive molecules described in the Heterocycles database (2011). However, further investigation is needed in order to determine the final chemical structure of the metabolites.

\section{ACKNOWLEDGEMENTS}

This work was supported by the "Ministère de l'Enseignement supérieur et de la Recherche Scientifique" (MESRS and ANDRU) of Algeria and the "Comité d'Evaluation et de Prospective de Coopération Interuniversitaire Franco-Algérienne (CMEP No. 02 MDU 


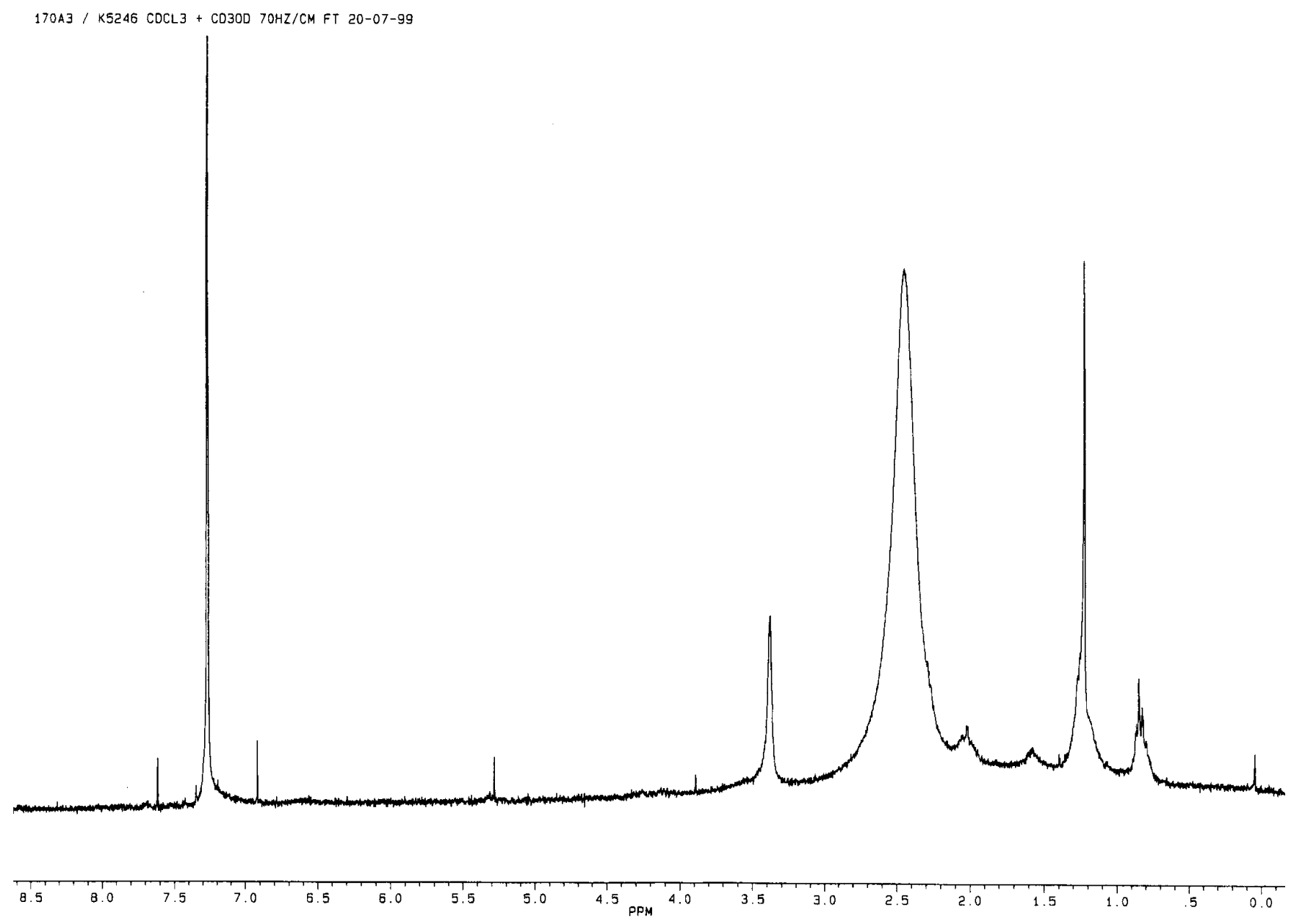

Figure 5. $\mathrm{H}$ NMR spectrum of the 170A2 molecule in $\mathrm{CDCl}_{3}$.

\section{4), French Embassy in Algiers."}

\section{REFERNECES}

Athalye M, Goodfellow M, Lacey J, White RP (1985). Numerical classification of Actinomadura and Nocardiopsis. Int. J. Syst. Bacteriol. 35: 86-98.

Badji B, Riba A, Mathieu F, Lebrihi A, Sabaou N (2005). Antifungal activity of a Saharan Actinomadura strain against various pathogenic and toxinogenic fungi. J. Med. Mycol. 15: 211-219.

Badji B, Zitouni A, Mathieu F, Lebrihi A, Sabaou N (2006). Antimicrobial compounds produced by Actinomadura sp. AC104, isolated from an Algerian Saharan soil. Can. J. Microbiol. 52: 373-382.

Berdy J (2005). Bioactive microbial metabolites. J. Antibiot. 58(1): 1-26.

Berdy J, Aszalos A, McNitt KL (1987). Handbook of antibiotic compounds. XIII. Microbial metabolites. CRC Press, Boca Raton, Fla. Vols. 1, 2, 3.

Betina V (1973). Bioautography in paper and thin layer chromatography and its scope in the antibiotic field. J. Chromatogr. 78: 41-51.

Dairi T, Hamano Y, Furumai T, OKI T (1999). Development of a self cloning system for Actinomadura verrucosospora and identification of polyketide synthase genes essential for production of the angucyclic antibiotic pradimicin. Appl. Environ. Microbiol. 65: 2703-2709.

Euzeby JP (2010). List of bacterial names with standing in nomenclature genus Actinomadura [online]. Available from http://www.bacterio.cict.fr./a/actinomadura.html.
Felsenstein J (1985). Confidence limits on phylogenies: an approach using the bootstrap. Evolution, 39: 783-791.

Gathogo EW, Waugh AC, Peric-Concha N, Redpath MB, Long PF (2004). Rapid detection of rare actinomycetes in environmental samples. Biotechnol. Lett. 26(11): 897-900.

Goodfellow M, Alderson G, Lacey J (1979). Numerical taxonomy of Actinomadura and related actinomycetes. J. Gen. Microbiol. 112: 95111.

Gordon RE, Barnett DA (1977). Resistance to rifampicin and lysozyme of isolates of some species of Mycobacterium and Nocardia as a taxonomic tool. Int. J. Syst. Bacteriol. 27: 176-178.

Gordon RE, Barnett DA, Handarhan JE, Hor-Nay-Pang C (1974). Nocardia coeliaca, Nocardia autrophica and the nocardin isolates. Int. J. Syst. Bacteriol. 24: 54-63.

Hedge V, Patel M, Horan A, Gullo V, Marquez J, Gunnarsson I, Gentile F, Loebenber D, King A, Puar M, Pramanik B (1992). Macrolactams: a novel class of antifungal antibiotics produced by Actinomadura spp. SC1776 and SCC 1777. J. Antibiot. 45: 624-632.

Heterocycles Database (2011). Natural Products with Heterocyclic Ring System. In International Journal for reviews and communications in Heterocycles chemistry, published online by the Japan Institute of heterocyclic WWW.//http.heterocycles.jp/structure/structure.php.

Jukes TH, Cantor CR (1969). Evolution of protein molecules. In Mammalian protein metabolism. Edited by H.N. Munro. Academic Press, New York. 3: 21-132.

Kakinuma S, Susuki H, Hatori M, Saitoh K, Hasegawa T, Furumai T, Oki T (1993). Biosynthesis of the pradimicin family of antibiotics. III. 
Biosynthetic pathway of both pradimicins and benanomicins. J. Antibiot. 46: 430-440.

Kumar S, Tamura K, Nei M (2004). MEGA3: Integrated software for molecular evolutionary genetic analysis and sequence alignment. Briefings Bioinf. 5: 150-163.

Marchal N, Bourdon JL (1973). Milieux de culture et identification biochimique des bactéries. Doin, Paris.

Miyadoh S (1993). Research on antibiotic screening in Japan over the last decade: a producing microorganism approach. Actinomycetologica, 7: 100-106.

Sabaou N, Boudjella H, Bennadji A, Mostefaoui A, Zitouni A, Lamari L, Bennadji H, Lefebvre G, Germain P (1998). Les sols du Sahara algérien, source d'actinomycètes rares producteurs d'antibiotiques. Sécheresse, 9: 147-153.

Saitou N, Nei M (1987). The neighbour joining method: a new method for reconstructing phylogenetic trees. Mol. Biol. Evol. 4: 406-425.

Shirling EB, Gottlieb D (1966). Methods for characterization of Streptomyces species. Int. J. Syst. Bacteriol. 16: 313-340.

Stackebrandt E, Gobel BM (1994). Taxonomic note: A place for DNADNA reassociation and 16S rRNA sequence analysis in the present species definition in bacteriology. Int. J. Syst. Bacteriol. 44: 846-849.

Terekhova LP, Galatenko OA, Alferova IV, Preobrazenskaya TP (1981). Comparative Appraisal of some inhibitors of bacterial growth used as selective agents for the isolation of soil actinomycetes. Antibiot. Kimiother. 36: 5-8.
Terekhova LP, Galatenko OA, Preobrazhenskaia TP, Tolstykh IV, Ol'khovatova OL, Malkina ND, Rubtsova EV (1991). Actinomadura species as antibiotic producers. Antibiot. Khimioter. 36(1): 3-5.

Thompson JD, Higgins DG, Gibson TJ (1994). Clustal W: improving the sensitivity of progressive multiple sequence alignment through sequence weighing, position specific gap penalties and weight matrix choice. Nucleic Acids Res. 22: 4673-4680.

Toropova EG, Egorov NS, Piskunova NF (1985). Biosynthetic activity of cultures of different species of the genus Actinomadura. Mikrobiologiia, 54(5): 719-723.

Yassin C, Siering SC, Klenk HP (2010). Actinomadura sputi sp. nov. isolated from the sputum of a patient with pulmonary infection. Int. J. Syst. Evol. Microbiol. 60: 149-153.

Zakharova OS, Zenova GM, Zvyagintsev DG (2003). Some approaches to the selective isolation of actinomycetes of the genus Actinomadura from soil. Microbiology, 72: 110-113.

Zhang Z, Kudo T, Nakajima Y, Wang Y (2001). Clarification of the relationship between the members of the family Thermomonosporaceae on the basis of 16S rDNA, 16S-23S rRNA internal transcribed spacer and 23S rDNA sequences and chemotaxonomic analyses. Int. J. Syst. Evol. Microbiol. 51: 373-383. 